\title{
Chryseobacterium indologenes in a woman with acute leukemia in Senegal: a case report
}

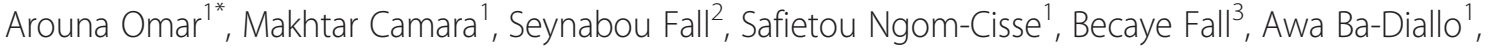 \\ Halimatou Diop-Ndiaye ${ }^{1}$, Coumba Toure-Kane ${ }^{1}$, Souleymane Mboup ${ }^{1}$ and Aissatou Gaye-Diallo ${ }^{1}$
}

\begin{abstract}
Introduction: This report documents a rare case of Chryseobacterium indologenes urinary tract infection in Senegal. Chryseobacterium indologenes is an uncommon human pathogen reported in hospital outbreaks in Taiwan and there have been some sporadic cases reported in Europe and in the USA mainly from immune-suppressed patients.

Case presentation: This case report describes a 42-year-old woman of Wolof ethnicity who was hospitalized in our Department of Internal Medicine in a Senegalese university teaching hospital, with acute leukemia who died of severe sepsis 10 days following her hospitalization. A strain of Chryseobacterium indologenes isolated from her urine sample was resistant to several beta-lactams including ampicillin (minimum inhibitory concentrations $\geq 256 \mu \mathrm{g} / \mathrm{mL}$ ), cefotaxime (minimum inhibitory concentrations $32 \mu \mathrm{g} / \mathrm{mL}$ ) and imipenem (minimum inhibitory concentrations $\geq 32 \mu \mathrm{g} / \mathrm{mL}$ ), whereas it was susceptible to piperacillin (minimum inhibitory concentrations $16 \mu \mathrm{g} / \mathrm{mL}$ ), cefepime (minimum inhibitory concentrations $4 \mu \mathrm{g} / \mathrm{mL}$ ), ceftazidime (minimum inhibitory concentrations $4 \mu \mathrm{g} / \mathrm{mL}$ ), trimethoprim-sulfamethoxazole (minimum inhibitory concentrations $\leq 0.25 \mu \mathrm{g} / \mathrm{mL}$ ) and all tested quinolones including nalidixic acid (minimum inhibitory concentrations $\leq 2 \mu \mathrm{g} / \mathrm{mL}$ ).
\end{abstract}

Conclusions: Chryseobacterium indologenes although uncommon, is an important pathogen causing infection in hospitalized patients. The management of this infection needs better identification, drug susceptibility testing and monitoring of immunosuppressed patients with long hospitalizations.

Keywords: Chryseobacterium indologenes, Leukemia, Metallo- $\beta$-lactamase, Resistance

\section{Introduction}

Chryseobacteria are a group of Gram-negative, nonfermenting, non-motile, catalase-, oxidase- and indolepositive aerobic bacilli. Chryseobacterium indologenes was first isolated from the tracheal aspirate of a patient with ventilator-associated pneumonia in 1993. Chryseobacterium species rarely cause human infections [1] but has been reported in nosocomial infections in Taiwan and rarely elsewhere [2]. In the hospital environment, $C$. indologenes is found in water systems, sink basins, the surfaces of equipment and wet medical devices (such as ventilators, humidifiers, and suction tubes) [3,4]. Despite their low virulence, Chryseobacteria are inherently resistant to many antimicrobial agents including imipenem.

\footnotetext{
* Correspondence: oarouna2@gmail.com

${ }^{1}$ Laboratoire de Bactériologie-Virologie, Université Cheikh Anta DIOP, CHU Aristide Le Dantec, BP 7325 Dakar, Senegal

Full list of author information is available at the end of the article
}

C. indologenes from urinary tract infection was reported in Burkina Faso, India and Spain [5-7]. In Senegal, two cases of meningitis due to Flavobacterium meningosepticum were diagnosed in the late-1970s [8], but $C$. indologenes has not been reported previously.

\section{Case presentation}

A 42-year-old woman of Wolof ${ }^{\text {a }}$ ethnicity, who underwent eight pregnancies (of which one was aborted), with chronic myeloid leukemia (CML), was admitted to our Intensive Care Unit (ICU) 1 year before this report for a tonic-clonic generalized seizure 11 days after a normal vaginal delivery (sixth child). At this date, a clinical examination showed a blood pressure of $130 / 70(\mathrm{mmHg})$, a fever of $37.6^{\circ} \mathrm{C}$ and a tachycardia of 125 beats per minute. Her Glasgow Coma Score (GCS) was 13/15 (E4M5V4) with reactive pupils and without localizing signs; her reflexes were present and normal. For biological parameters, no albumin was found in her urine or at blood 
level; hypernatremia of $148 \mathrm{mEq} / \mathrm{L}$, hypokalemia $2.4 \mathrm{mEq} / \mathrm{L}$, anemia $11.6 \mathrm{~g} / \mathrm{dL}$, thrombocytosis of $729,000 / \mathrm{mm}^{3}$ and a leukocytosis of 123,000 white blood cells (WBC)/mL (lineage not given). After symptomatic treatment including rehydration, her GCS returned to $15 / 15$ and her serum electrolytes normalized, she was then referred to hematology for further investigation.

The diagnosis of CML was confirmed by a myelogram and a finding of Bcr-Abl fusion positive genotype (Philadelphia chromosome) a year prior to her ICU hospitalization. She was then treated with imatinib (mesylate) $100 \mathrm{mg}$ (Glivec ${ }^{\circ}$ ) under a standard protocol of two tablets two times a day. This treatment continued until the beginning of her subsequent, seventh pregnancy at an unknown time.

Two months after giving birth (eighth pregnancy), she was hospitalized again (day 0), with hepatomegaly, splenomegaly type IV according to Hackett's classification, an anemic syndrome and an infectious syndrome with a temperature of $38.8^{\circ} \mathrm{C}$. Her blood count showed leukocytosis of $275,000 \mathrm{WBC} / \mathrm{mL}$ cells with $40 \%$ of blast cells, therefore an acute crisis of her CML was suspected. An abdominal ultrasound confirmed a homogeneous hepatosplenomegaly without signs of portal hypertension. Blood culture and urine culture were requested, but not performed due to lack of finance. Glivec ${ }^{\circ}$ (imatinib) was given at a dose of $600 \mathrm{mg}$ per day. Empirical antibiotic therapy of ceftriaxone $2 \mathrm{~g}$ daily was administered. It is only on day 7 that a urine sample was taken for cytology and bacteriology examination at a laboratory. She did not recover, by day 8 she was in septic shock and she subsequently died on day 10 with severe sepsis.

The urine received from the day before her death was clear with a rich bacterial flora but few cells in cytology. Microscopy showed Gram-negative bacilli. Her urine was inoculated on cysteine lactose electrolyte deficient (CLED) agar in accordance with the usual techniques of medical bacteriology. The CLED agar grew yellow-colored, 1 to $2 \mathrm{~mm}$ circular colonies $\left(>10^{7} \mathrm{CFU} / \mathrm{mL}\right.$ ) with regular margins. Similar yellow-pigmented colonies were also observed on Müller-Hinton Agar (Figure 1). The flexirubin type of pigment was confirmed by adding 1 drop of $10 \%$ sodium hydroxide solution to a bit of cell paste. The color of the colonies changed from yellow to red (Figure 1).

After culture, C. indologenes was suspected by microscopy examination and biochemical tests (Gram-negative bacilli that were non-motile, produced oxidase, catalase, and urease and indole). C. indologenes was confirmed using the Appareil et Procédés d'Identification 20NE identification system (bioMérieux, France; excellent identification \% $\mathrm{Id}=99.9$ and $\mathrm{T}=0.82$ ). The genus Chryseobacterium was confirmed by mass spectrometry (Vitek MS matrix-assisted laser desorption/ionization, time-of-flight, bioMérieux)

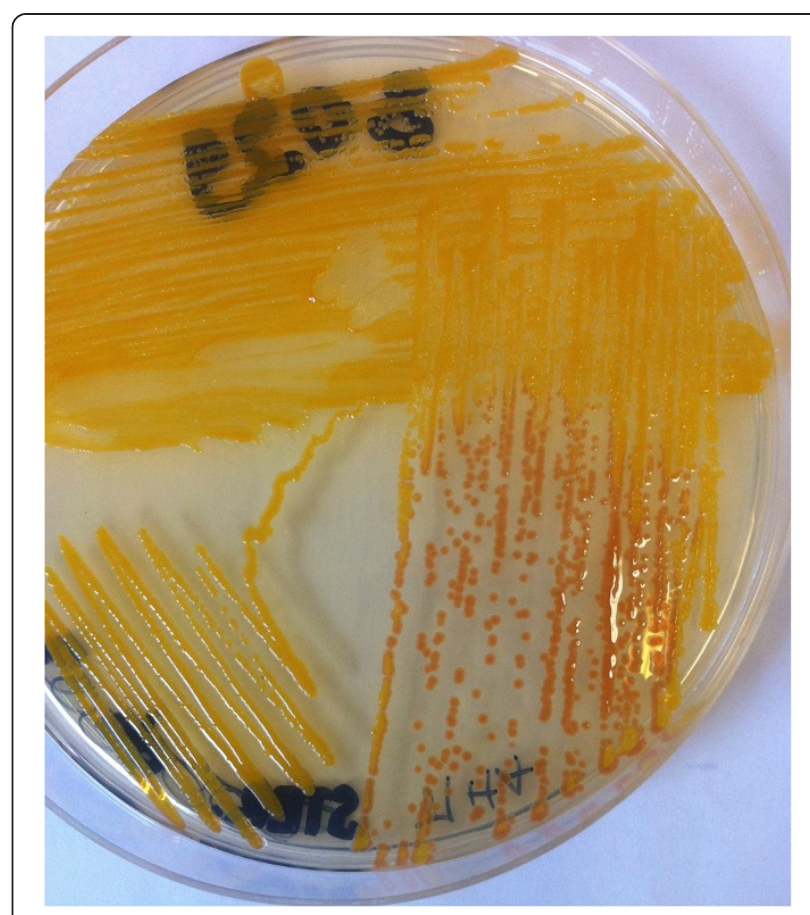

Figure 1 Yellow-pigmented colonies changed from yellow to red by adding 1 drop of $10 \%$ sodium hydroxide (flexirubin).

in an army teaching hospital (Figure 2). Antimicrobial susceptibility testing by disc diffusion and dilution on microplate for minimal inhibition concentration methods using Pseudomonas aeruginosa ATCC 27853 and Escherichia coli ATCC 25922 for internal quality control was done and interpreted according to the Comité d'Antibiogramme de la Société Française de Microbiologie recommendations of 2013. This strain was susceptible to piperacillin, ceftazidime, trimethoprim-sulfamethoxazole, and quinolone including nalidixic acid and resistant to cefotaxime, aztreonam, imipenem, gentamicin, amikacin, tobramycin, and colistin (Table 1). A test for metallo- $\beta$ lactamase $(\mathrm{MBL})$ was done and the result was positive (Figure 3). Hydrolysis tests performed with imipenem (substrate) and a crude extract of a liquid medium culture of our strain, the objective being the production of betalactamase, by measuring the absorbance variation with a Cary 100 UV-visible spectrophotometer (Varian, Walnut Creek, CA, USA). Imipenem hydrolysis activity inhibited $(>90 \%)$ after incubation with $5 \mathrm{mM}$ ethylenediaminetetraacetic acid, revealed the presence of an MBL. To characterize the gene encoding MBL of the strain, polymerase chain reaction (PCR) was carried out using genomic deoxyribonucleic acid (DNA) obtained by phenol-chloroform extraction, as the template primers IND-INV $/+$ (5' ${ }^{\prime}$ TTGGCAGAATATTCTTTACC $)$ and IND-INV/- (5' -GAAAAAAAGACGGAAAAGCAAC) as described previously by Bellais and coworkers [9]. 


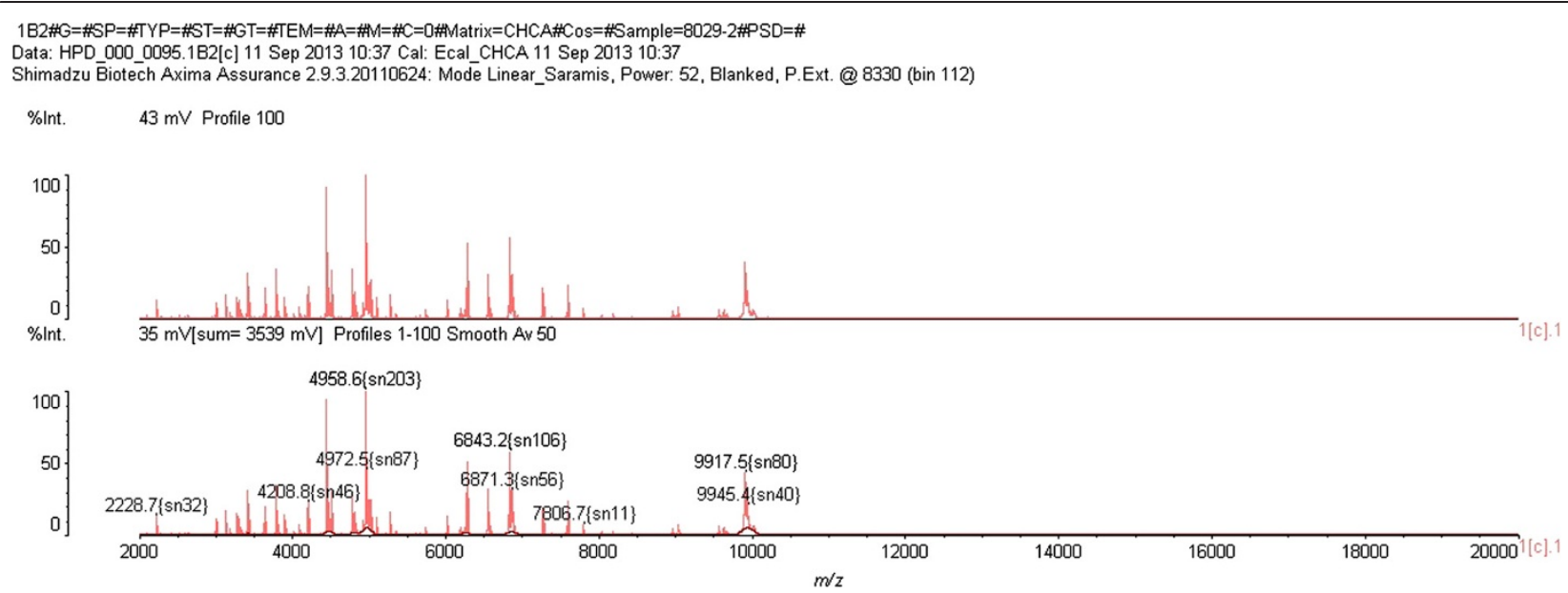

Figure 2 Mass spectral profile.

\section{Discussion}

Chryseobacterium is an uncommon pathogen reported to have caused hospital-acquired infection in Taiwan. Six cases have been reported in Europe, two in Australia, two in India and seven in the USA [6]. To the best of our knowledge, this case report of $C$. indologenes infection is the second in Africa, the first was described in Burkina Faso in 2009 [5].

The pathogenicity of $C$. indologenes is not well established, however, it is already known that biofilm and proteases production are important mechanisms involved in its virulence [10]. Chryseobacterium is often encountered in water, soil and plants. Resistant to chlorination, it is found in the hospital environment at water systems and on medical equipment. Colonization of patients via contaminated medical devices involving fluids such as respirators, intubation tubes, humidifiers, and incubators for newborns has been reported [10]. The rehabilitation of our Department of Internal Medicine just after the death of our patient, has not allowed us to take environmental samples to investigate the source of infection.

The associated infections involve the blood stream, pneumonia, intra-abdominal and urinary tract $[6,7,11]$ and the main risk factors are oncological disease, long hospital stays and prolonged antibiotic treatment $(>14$ days) [10-12]. Our patient had CML, which evolved into an acute leukemia and she was hospitalized with infectious syndrome. A blood culture was requested but it was not done due to lack of financial resources. Clinical data allow us to state that she died of septicemia; however, the isolation of the bacterium only in her urine does not allow us to confirm that it is responsible, although urinary tract infection criteria are met. Nevertheless, it is possible that the bacterium was responsible for septicemia due to her immunocompromised state;
Table 1 In vitro antimicrobial susceptibilities of the strain, and interpretation according to Comité d'Antibiogramme de la Société Française de Microbiologie 2013 recommendations, using Pseudomonas aeruginosa ATCC $\mathbf{2 7 8 5 3}$ and Escherichia coli ATCC 25922 as quality control

\begin{tabular}{|c|c|c|c|c|c|}
\hline \multirow[t]{2}{*}{ Antibiotics } & \multirow{2}{*}{$\begin{array}{l}\text { MIC } \\
(\mu \mathrm{g} / \mathrm{mL})\end{array}$} & \multirow{2}{*}{$\begin{array}{l}\text { IZD } \\
(\mathrm{mm})\end{array}$} & \multicolumn{2}{|c|}{ Breakpoint (S) } & \multirow[t]{2}{*}{ Categorization } \\
\hline & & & $\mu \mathrm{g} / \mathrm{mL}$ & $\mathrm{mm}$ & \\
\hline Ampicillin & $\geq 256$ & 0 & $\leq 16$ & $\geq 22$ & Resistant \\
\hline Piperacillin & 16 & 20 & $\leq 16$ & $\geq 18$ & Susceptible \\
\hline Ticarcillin & $\geq 256$ & 0 & $\leq 16$ & $\geq 22$ & Resistant \\
\hline Temocillin & $\geq 256$ & 0 & $\leq 16$ & $\geq 22$ & Resistant \\
\hline Cephalothin & $\geq 256$ & 0 & $\leq 16$ & $\geq 22$ & Resistant \\
\hline Cefuroxime & $\geq 256$ & 0 & $\leq 16$ & $\geq 22$ & Resistant \\
\hline Cefotaxime & 32 & 8 & $\leq 16$ & $\geq 22$ & Resistant \\
\hline Ceftazidime & 4 & 25 & $\leq 08$ & $\geq 19$ & Susceptible \\
\hline Ceftriaxone & 32 & 8 & $\leq 16$ & $\geq 22$ & Resistant \\
\hline Cefepime & 4 & 28 & $\leq 08$ & $\geq 19$ & Susceptible \\
\hline Cefotetan & $\geq 32$ & 6 & $\leq 16$ & $\geq 22$ & Resistant \\
\hline Imipenem & $\geq 32$ & 6 & $\leq 04$ & $\geq 22$ & Resistant \\
\hline Meropenem & 32 & 6 & $\leq 02$ & $\geq 22$ & Resistant \\
\hline Ertapenem & $\geq 32$ & 6 & $\leq 02$ & $\geq 22$ & Resistant \\
\hline Aztreonam & $\geq 32$ & 8 & $\leq 01$ & $\geq 27$ & Resistant \\
\hline $\begin{array}{l}\text { Trimethoprim- } \\
\text { sulfamethoxazole }\end{array}$ & $\leq 0.25$ & 22 & $\leq 2$ & $\geq 16$ & Susceptible \\
\hline Nalidixic acid & $\leq 2$ & 28 & $\leq 08$ & $\geq 20$ & Susceptible \\
\hline Gentamicin & ND & 4 & ND & $\geq 16$ & Resistant \\
\hline Amikacin & ND & 0 & ND & $\geq 17$ & Resistant \\
\hline Tobramycin & ND & 0 & ND & $\geq 16$ & Resistant \\
\hline Colistin & ND & 0 & ND & - & Resistant \\
\hline
\end{tabular}

Abbreviations: IZD, inhibition zone diameter; MIC, minimum inhibitory concentration. 'ND', Not Determined; '-' Colistin breakpoint not given. S, sensitivity. 


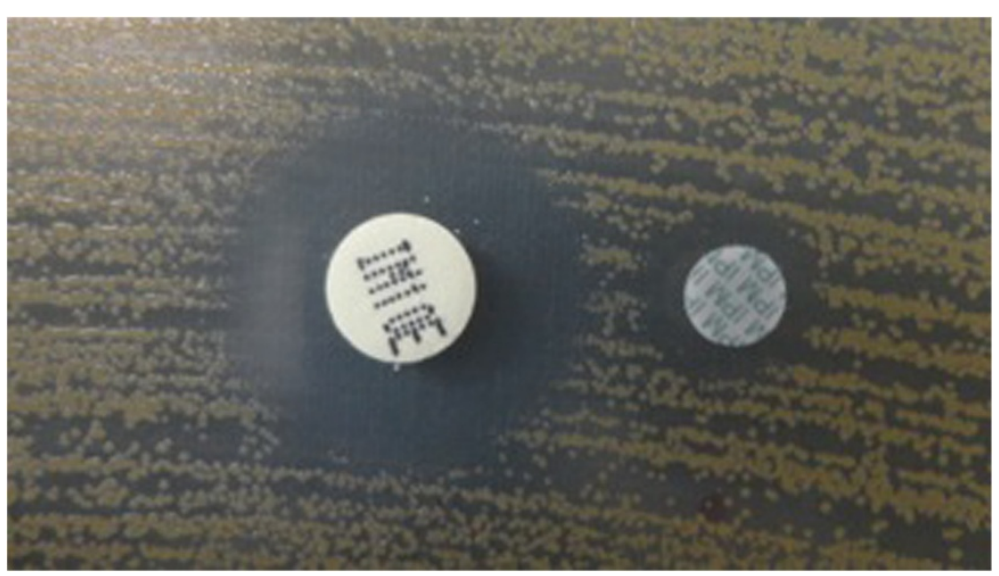

Figure 3 Evidence of metallo- $\beta$-lactamase producing resistance to imipenem with double-disc synergy test (ethylenediaminetetraacetic acid and imipenem).

several cases of bacteremia due to $C$. indologenes have been published [11]. The majority of the cases reported in the literature with infections caused by $C$. indologenes had critical diseases and, frequently, polymicrobial infections.

Only $0.03 \%$ (50 of 155,811) of all bacterial isolates collected by the SENTRY Antimicrobial Surveillance Program [13] during the 5-year period 1997 to 2001 were members of the genera Chryseobacterium or Elizabethkingia (formerly Chryseobacterium), the most frequent organisms being Elizabethkingia meningoseptica (formerly Chryseobacterium meningosepticum), C. indologenes and Chryseobacterium gleum [14]. All 50 isolates were from hospitalized patients, and the vast majority was recovered from either the lower respiratory tract (52.0\%) or blood cultures (46.0\%). Among the isolates from bloodstream infections, $30.4 \%$ were $C$. indologenes.

According to the results of the SENTRY Antimicrobial Surveillance Program, the antimicrobials most active against $C$. indologenes are the quinolones and trimethoprimsulfamethoxazole ( $\geq 95 \%$ susceptibility), followed by piperacillin-tazobactam (90\% susceptibility). Ciprofloxacin, cefepime, ceftazidime, piperacillin, and rifampin showed reasonable activity ( $85 \%$ susceptibility), whereas aminoglycosides, other $\beta$-lactams, chloramphenicol, linezolid, and glycopeptides are not appropriate for treating infections by this organism [13]. The strain was found to be resistant to imipenem (minimum inhibitory concentrations, MICs, $\geq 32 \mu \mathrm{g} / \mathrm{mL}$ ) due to MBL (class B) production and susceptible to piperacillin (MICs $16 \mu \mathrm{g} / \mathrm{mL}$ ), cefepime (MICs $4 \mu \mathrm{g} / \mathrm{mL}$ ), ceftazidime (MICs $4 \mu \mathrm{g} / \mathrm{mL}$ ) trimethoprim-sulfamethoxazole (MICs $\leq 0.25 \mu \mathrm{g} / \mathrm{mL}$ ) and all quinolones including nalidixic acid (MICs $\leq 2 \mu \mathrm{g} / \mathrm{mL}$ ). It is also resistant to ceftriaxone (MICs $32 \mu \mathrm{g} / \mathrm{mL}$ ), used as empirical antibiotic therapy for our patient. Our strain seemed to be less resistant than C. indologenes 597 (IND-6) of Burkina Faso according to MIC of imipenem $(\geq 32 \mu \mathrm{g} / \mathrm{mL}$ versus $\geq 64 \mu \mathrm{g} / \mathrm{mL})$ and quite more resistant than C. indologenes NF 16 (CDC group IIb, IND-5) $(\geq 32 \mu \mathrm{g} / \mathrm{mL}$ versus $32 \mu \mathrm{g} / \mathrm{mL})$. Several species of Flavobacteriaceae, including $C$. indologenes, are naturally resistant to $\beta$-lactam antibiotics (including carbapenems) due to production of a resident MBL (class B) IND-1 for indologenes [9]. Seven variants of MBL (class B; IND-1 to IND-6 and IND-2a) have been detected in C. indologenes. A new IND-type variant named IND-7 has also been recently reported from Japan (2010) in a C. indologenes isolate [15]. Nonspecific bands obtained by PCR-IND for our strain can be explained by the sequence heterogeneity at the $5^{\prime}$ and $3^{\prime}$ extremities of the MBL gene, which made unsuccessful direct amplification with consensus primers designed to amplify all known IND-like MBL genes. An inverse PCR approach to obtain the complete sequence of the $b l a_{I N D}$ of our strain is in progress.

\section{Conclusions}

C. indologenes although uncommon, is an important pathogen causing infection in hospitalized patients. The management of this infection needs better identification, susceptibility testing and monitoring of immunocompromised patients with long hospital stays. In addition, this report showed the necessity to survey environmental bacteria that could cause hospital-acquired infection.

\section{Consent}

The signed written consent of the husband of the deceased patient was obtained for publication of this case report and the accompanying images after explaining the interest of this publication. A copy of the written consent is available for review by the Editor-in-Chief of this journal.

\section{Endnote}

${ }^{a}$ An ethnic group in Senegal, West Africa. 


\section{Competing interests}

All authors declare that they have no competing interests.

\section{Authors' contributions}

AO, CM, FS, NCS, FB, BDA, DNH, TKC, MS and GDA conducted the case review and contributed to the writing of the case report. All authors read and approved the final report.

\section{Acknowledgments}

We thank practitioners of our Department of Internal Medicine for clinical data and the staff of the Laboratory of Bacteriology of the Aristide Le Dantec University Hospital for their technical assistance.

We also thank the researchers of the Department of Medical Biotechnology, University of Siena (Italy), where work continues on the stump.

Last but not least we also address thanks to Jean-Pierre Nguessan (WANETAM) for helpful comments.

\section{Author details}

'Laboratoire de Bactériologie-Virologie, Université Cheikh Anta DIOP, CHU Aristide Le Dantec, BP 7325 Dakar, Senegal. ²Service de Médecine Interne, Université Cheikh Anta DIOP, CHU Aristide Le Dantec, Dakar, Senegal. ${ }^{3}$ Hôpital Principal de Dakar, 1, Avenue Nelson Mandéla, BP 3006 Dakar, Senegal.

Received: 24 September 2013 Accepted: 19 March 2014 Published: 6 May 2014

\section{References}

1. Douvoyiannis M, Kalyoussef S, Philip G, Mayers MM: Chryseobacterium indologenes bacteremia in an infant. Int J Infect Dis 2010, 14(6):e 531-e 532.

2. Hsueh PR, Teng $\sqcup$, Yang PC, Ho SW, Hsieh WC, Luh KT: Increasing incidence of nosocomial Chryseobacterium indologenes infections in Taiwan. Eur J Clin Microbiol Infect Dis 1997, 16(8):508-574

3. Calderon G, Garcia E, Rojas P, Garcia E, Rosso M, Losada A Chryseobacterium indologenes infection in a newborn: a case report. J Med Case Rep 2010, 5:10.

4. Lin YT, Jeng YY, Lin ML, Yu KW, Wang FD, Liu CY: Clinical and microbiological characteristics of Chryseobacterium indologenes bacteremia. J Microbiol Immunol Infect 2010, 43:498-505.

5. Zeba B, De Luca F, Dubus A, Delmarcelle M, Simpore J, Nacoulma JO, Rossolini GM, Frere JM, Docquier JD: IND-6, a highly divergent IND-type metallo-beta-lactamase from Chryseobacterium indologenes strain 597 isolated in Burkina Faso. Antimicrob Agents Chemother 2009, 53:4320-4326

6. Bhuyar G, Jain S, Shah H, Mehta VK: Urinary tract infection by Chryseobacterium indologenes. Indian J Med Microbiol 2012, 30:370-372.

7. Acosta-Ochoa Ml, Rodrigo-Parra A, Rodríquez-Martín F, Molina-Miguel A: Urinary infection due to Chryseobacterium indologenes. Nefrologia 2013, 19:33(4).

8. Samb A, Chiron JP, Denis F, Sow A, Diop Mar I: Flavobacterium meningosepticum meningitis. Clinical and bacteriological study of 2 cases treated in Senegal. Bull Soc Med A 1977, 22(1):84-91.

9. Bellais S, Poirel L, Leotard S, Naas T, Nordmann P: Genetic diversity of carbapenem-hydrolyzing metallo-b-lactamases from Chryseobacterium (Flavobacterium) indologenes. Antimicrob Agents Chemother 2000, 44:3028-3034.

10. Hsueh PR, Teng LJ, Yang PC, Ho SW, Hsieh WC, Luh KT: Clinical and microbiological characteristics of Flavobacterium indologenes infections associated with indwelling devices. J Clin Microbiol 1908-1913, 1996:34.

11. Christakis GB, Perlorentzou SP, Chalkiopoulou I, Athanasiou A, Legakis NJ: Chryseobacterium indologenes non-catheter-related bacteremia in a patient with a solid tumor. J Clin Microbiol 2005, 43(4):2021-2023.

12. Chen FL, Wang GC, Teng SO, Ou TY, Yu FL, Lee WS: Clinical and epidemiological features of Chryseobacterium indologenes infections: analysis of 215 cases. J Microbiol Immunol Infect 2013, 46(6):425-432.

13. Kirby JT, Sader HS, Walsh TR, Jones RN: Antimicrobial susceptibility and epidemiology of worldwide collection of Chryseobacterium spp. Report from the SENTRY Antimicrobial surveillance Program (1997-2001). J Clin Microbiol 2004, 42:445-448.
14. Bernardet JF, Hugo C, Bruun B: The Genera Chryseobacterium and Elizabethkingia. The Prokaryotes, 7. New York: Springer; 2006:638-676.

15. Yamaguchi Y, Takashio N, Wachino J, Yamagata Y, Arakawa Y, Matsuda K, Kurosaki $\mathrm{H}$ : Structure of metallo-beta-lactamase IND-7 from a Chryseobacterium indologenes clinical isolate at 1.65-A resolution. J Biochem 2010, 147(6):905-915.

doi:10.1186/1752-1947-8-138

Cite this article as: Omar et al:: Chryseobacterium indologenes in a woman with acute leukemia in Senegal: a case report. Journal of Medical Case Reports 2014 8:138.

\section{Submit your next manuscript to BioMed Central and take full advantage of:}

- Convenient online submission

- Thorough peer review

- No space constraints or color figure charges

- Immediate publication on acceptance

- Inclusion in PubMed, CAS, Scopus and Google Scholar

- Research which is freely available for redistribution 